Guchhait, R. \& Ganguli, N. C. (1960). Abstr. Symp. Biochemical Aspects of Cholesterol Metabolism and Atherosclerosis, p. 8.

Guchhait, R. \& Ganguli, N. C. (1961a). Biochim. biophys. Acta, 51, 607.

Guchhait, R. \& Ganguli, N. C. (1961b). J. sci. industr. Res. $20 \mathrm{C}, 195$.

Hogeboom, G. H. (1955). In Methods in Enzymology, vol. 1, p. 16. Ed. by Colowick, S. P. \& Kaplan, N. O. New York: Academic Press Inc.

Horning, M. G., Fredrickson, D. S. \& Anfinsen, C. B. (1957). Arch. Biochem. Biophys. 71, 266.

Katz, J. \& Chaikoff, I. L. (1954). J. biol. Chem. 206, 887.

Kritchevsky, D. (1958). In Cholesterol, p. 115. New York: John Wiley and Sons. Inc.
Lynn, W. S., Staple, E. \& Gurin, S. (1955). Fed. Proc. 14, 783.

Ma, T. S. \& Zuazaga, G. (1942). Industr. Engng Chem. (Anal.) 14, 280.

Oesterling, M. J. \& Long, G. N. H. (1951). Science, 113, 241.

Sealock, R. R. \& Silberstein, H. E. (1940). J. biol. C'hem. 135, 251.

Siperstein, M. D. \& Chaikoff, I. L. (1955). Fed. Proc. 14, 767.

Siperstein, M. D., Jayko, M. E., Chaikoff, I. L. \& Dauben, W. G. (1952). Proc. Soc. exp. Biol. N.Y., 81, 720.

Sperry, W. M. \& Webb, M. (1950). J. biol. Chem. 187, 97.

Whitehouse, M. W., Staple, E. \& Gurin, S. (1959). J. biol. Chem. 234, 276.

Biochem. J. (1963) 86, 197

\title{
The Catabolism of Proteins and Nucleic Acids in Starved Aerobacter aerogenes
}

\author{
By R. E. STRANGE, H. E. WADE AND A. G. NESS \\ Microbiological Research Establishment, Porton, Wilts.
}

(Received 7 June 1962)

Previous studies on the longevity of starved stationary-phase Aerobacter aerogenes indicated that, before the death of a significant proportion of the population, losses of substantial amounts of protein, RNA and (if initially present) glycogen occurred (Strange, Dark \& Ness, 1961; Strange, 1961). The analysis of the suspending fluid during starvation showed that ammonia, nucleic acid bases and inorganic phosphate had been released to an extent that suggested their origin from macromolecules.

There have been several reports of substantial losses of RNA from suspensions of starved viable bacteria (Borek, Ryan \& Rockenbach, 1955; Rotman, 1958; Holden, 1958) and yeasts (Higuchi \& Uemura, 1959). Since most of the RNA and a substantial fraction of the total protein are present in the ribosomes (Tissieres, Watson, Schlessinger \& Hollingworth, 1959), it appeared likely that the latter suffered these losses. To determine to what extent the total losses of RNA and protein could be accounted for in this way, the changes in compositions of sedimentation fractions from starved $A$. aerogenes were followed. In addition, the extent to which these losses could be accounted for by substances released into the suspending fluid was examined.

\section{MATERIALS AND METHODS}

Cultural conditions. Aerobacter aerogenes (N.C.T.C. 418), originally obtained from Professor Sir Cyril Hinshelwood's Laboratory, was grown either on tryptic meat broth, pre- pared from bullock's meat as described for Hartley's broth (Mackie \& McCartney, 1948) and diluted with water to give a concentration of $2.5 \mathrm{mg}$. of $\mathrm{N} / \mathrm{ml}$. or on a carbonlimiting defined medium $(11 \mathrm{~N})$, which contained $1 \%$ (w/v) of mannitol, prepared as described by Strange et al. (1961).

The bacteria were grown in 31 . of medium at $37^{\circ}$ with adequate aeration and at a controlled $\mathrm{pH}(\mathbf{7 \cdot 2 )}$ in the apparatus described by Strange et al. (1961). When growth, as determined by turbidity, had ceased for $0.5 \mathrm{hr}$. the bacteria were sedimented by centrifuging, washed with 20 vol. of buffered saline ( $0.02 \mathrm{M}$-potassium orthophosphate in $0.13 \mathrm{M}-\mathrm{NaCl}$ at $\mathrm{pH} 6.5$ ) and resuspended in the same solution (4-5 mg. dry wt. $/ \mathrm{ml}$., equivalent to $1 \times 10^{10_{-}}$ $2.5 \times 10^{10}$ viable bacteria $/ \mathrm{ml}$.).

Starvation. Suspensions of freshly harvested and washed bacteria were incubated at $37^{\circ}$ in a gas wash-bottle as described by Strange et al. (1961). A reflux water condenser, closed with a cotton-wool filter, was fitted to the outlet to prevent a volume change during starvation.

Viability. The viability was determined by two methods. The proportion of viable bacteria was determined directly by a slide culture technique (Postgate, Crumpton \& Hunter, 1961) in which the growth of viable bacteria on tryptic-meat-broth-agar is observed directly under a microscope by dark-ground illumination. The reproducibility of the method has been discussed previously (Postgate et al. 1961; Strange et al. 1961). The concentration of viable bacteria was determined by plate count on trypticmeat-broth-agar; the determination was carried out in duplicate and the coefficient of variation was about $\pm 6 \%$.

Sedimentation fractionation. A measured volume of bacterial suspension ( $280 \mathrm{ml}$.) was centrifuged at $11000 \mathrm{rev}$./ min. for $15 \mathrm{~min}$. in a MSE no. 13 angle centrifuge and the deposit was washed with a solution of $5 \mathrm{~mm}-\mathrm{MgCl}_{2}$ in 
$0 \cdot 145 \mathrm{M}-\mathrm{NaCl}(6 \mathrm{vol}$.) by centrifuging. The deposit (5-6 g. wet wt., depending on the initial concentration of the bacteria and the period of starvation, was mixed with $0.5 \mathrm{ml}$. of a solution of $5 \mathrm{~mm}-\mathrm{MgCl}_{2}$ in $0.145 \mathrm{M}-\mathrm{NaCl}$ and the bulk of it was passed through a Hughes (1951) press held initially at $-30^{\circ}$. All subsequent operations were carried out at $0-3^{\circ}$.

The disrupted bacteria were either diluted directly to $8-10 \%(\mathrm{w} / \mathrm{v})$ wet wt. (equivalent to $16-20 \mathrm{mg}$. dry wt. of bacteria/ml.) with a solution of $5 \mathrm{mM}-\mathrm{MgCl}_{2}$ in $0.145 \mathrm{M}$ $\mathrm{NaCl}$ (Expts. 1 and 2) or mixed for 30 sec. in a MSE no. 7700 homogenizer $[20 \%(\mathrm{w} / \mathrm{v})$ wet wt.] before diluting to this concentration (Expts. 3-6).

The sedimentation fractionation was as described for Escherichia coli by Wade (1961). The suspension of disrupted bacteria was centrifuged for $1 \mathrm{hr}$. at $25000 \mathrm{~g}$ in a Spinco model $\mathrm{L}$ centrifuge (no. 30 rotor) at $0^{\circ}$. The deposit $(R \mathrm{I})$ was made up to the original volume with a solution of $5 \mathrm{mM}-\mathrm{MgCl}_{2}$ in $0 \cdot 145 \mathrm{M}-\mathrm{NaCl}$; the supernatant was centrifuged for $7.5 \mathrm{hr}$. at $78000 \mathrm{~g}$. The deposit $(R \mathrm{II})$ and the supernatant $(S I I)$ were made up to the original volume in the same salt solution. The result of washing fraction $R \mathrm{II}$, which contained the ribosomes, with a solution of $5 \mathrm{~mm}$ $\mathrm{MgCl}_{2}$ in $0 \cdot 145 \mathrm{M}-\mathrm{NaCl}$ by a second centrifuging was to reduce the dry wt. of this fraction by $15 \%$ without greatly altering the protein:RNA ratio. This step was therefore omitted.

Determination of nucleic acid. A modified Schneider (1945) procedure was used. Samples were treated with $0 \cdot 25 \mathrm{~N}-\mathrm{HClO}_{4}$ at $0-3^{\circ}$ for $30 \mathrm{~min}$. The insoluble fraction was sedimented by centrifuging and the nucleic acids were solubilized by two extractions with $0.5 \mathrm{~N}-\mathrm{HClO}_{4}\left(70^{\circ}\right.$ for $15 \mathrm{~min}$.). The RNA in the combined extracts was estimated by the Dische \& Borenfreund (1957) method as modified by Bolognani, Coppi \& Zambotti (1961), with, as standard, undried yeast RNA (Boehringer und Soehne G.m.b.H., Mannheim, Germany) which contained $8.1 \%$ of total $P$ and was therefore assumed to contain $85 \%$ of RNA. DNA was estimated by the Burton (1956) modification of the diphenylamine reaction, with a standard of undried calfthymus DNA supplied by Dr D. Herbert. The standard was assumed to contain $78 \%$ of DNA based on determinations of total $\mathrm{N}$ and $\mathrm{P}$.

Determination of protein. Protein was determined by means of a biuret method (Stickland, 1951) after the sample had been dissolved by heating in $\mathrm{N}-\mathrm{NaOH}$ for 5 min. at $100^{\circ}$. Dried bovine plasma albumin (fraction V; Armour and Co. Ltd., Eastbourne), containing $15.9 \%$ of $\mathrm{N}$, was used as a standard. Since tris gives a positive reaction under these conditions, it was necessary to precipitate the protein with trichloroacetic acid $(5 \%, w / v)$ when this buffer was present.

Analysis for base and nucleoside. Bacteria grown in $11 \mathrm{~N}$ medium ( $5 \mathrm{mg}$. dry wt. of bacteria $/ \mathrm{ml}$.) were kept at $37^{\circ}$ in water with aeration for $24 \mathrm{hr}$. Water was used as the suspending fluid in place of buffered saline so that the salt content of the isolated substances would be low. After centrifuging, the supernatant was filtered through Oxoid membrane (grade AP, Oxo Ltd.) and freeze-dried (30 mg.). A solution of $15 \mathrm{mg}$. in $20 \mathrm{ml}$. of $0.01 \mathrm{M}$-ammonium formate was delivered on to a column (1 cm. diam.) of $20 \mathrm{ml}$. of Dowex 1 (200-400 mesh; formate form; X2) resin and eluted with $0.04 \mathrm{M}$-ammonium formate (flowing at $1 \mathrm{ml}$./ min.) adjusted with $\mathrm{HCl}$ to $\mathrm{pH} 5$ and to progressively lower
$\mathrm{pH}$ values at the rate $0 \cdot 166 \mathrm{pH} / \mathrm{hr}$. (Wade, 1960). A continuous recording of the ultraviolet absorption of the effluent (Lovett \& Wright, 1961) showed that it contained a large quantity of bases, in two fractions which were eluted during the first $2 \mathrm{hr}$., but few nucleotides. These fractions were adsorbed separately on $10 \mathrm{ml}$. of Dowex 1 (200-400 mesh; $\mathrm{OH}^{-}$form; X2), washed with water and then eluted with $10 \mathrm{ml}$. of $10 \%(\mathrm{v} / \mathrm{v})$ formic acid. The eluate was dried down, dissolved in water and fractionated by paper ionophoresis with a propionate buffer at $\mathrm{pH} \mathrm{3.5}$ (Wade \& Lovett, 1961); the mobilities of the ultravioletabsorbing constituents were compared with those of known bases and nucleosides.

Detection and estimation of amino acids. The bacteria were separated from the suspending fluid by centrifuging. The supernatant was filtered through Oxoid membrane (grade AP, Oxo Ltd.), then electrolytically desalted and concentrated. The free amino acids were separated by twodimensional ascending chromatography, with phenol saturated with water in an atmosphere of $\mathrm{NH}_{3}$ as the first solvent and butanol-acetic acid-water $(4: 1: 5$, by vol., upper phase) as the second solvent, and detected with ninhydrin reagent. An estimate of the total amino acids in the bacteria was obtained by extracting the deposit with $0.5 \mathrm{~N}-\mathrm{HClO}_{4}$ at $0^{\circ}$ for $30 \mathrm{~min}$., and determining the ninhydrin-reacting substances in the neutralized (with $\mathrm{KOH}$ ) extract (Yemm \& Cocking, 1955), with alanine as a standard.

Determination of nitrogen. Total $\mathrm{N}$ was determined by a Kjeldahl nesslerization procedure, and $\mathrm{NH}_{3} \mathrm{~N}$ by nesslerization after steam-distillation of the sample with alkaline buffer (Tracey, 1952) in a Markham still.

Determination of dry weight. Bacteria (20-25 mg. dry wt.) were centrifuged from a measured volume of bacterial suspension in a weighed tube, washed once with $5 \mathrm{ml}$. of $0.85 \%(\mathrm{w} / \mathrm{v}) \mathrm{NaCl}$ in $3 \%(\mathrm{w} / \mathrm{v})$ formaldehyde and finally with $5 \mathrm{ml}$. of water. The deposit was dried at $100^{\circ}$ for $16 \mathrm{hr}$. and weighed. Each determination was carried out in quadruplicate, the individual values of which did not vary by more than $0.5 \%$ of the mean.

\section{RESULTS}

Viability and dry weight of bacterial suspensions. The average mean mass of individual bacteria freshly harvested from tryptic meat broth and $11 \mathrm{~N}$ medium were $0 \cdot 24$ and $0 \cdot 38 \mu \mu$ g. respectively. On starvation for $41 \mathrm{hr}$., changes in viability of suspensions did not usually exceed $10 \%$, and average losses of dry wt. were 23 and $18 \%$ respectively in the two media (Table 1). The losses of dry wt. were almost entirely accounted for by losses of protein and RNA from the bacteria (see Table 3). The average initial concentrations of protein and RNA in suspensions of bacteria grown in tryptic meat broth were 74 and $10.8 \%$ respectively, and in $11 \mathrm{~N}$ medium 68 and $18 \%$ respectively.

Influence of the suspending fuid on the sedimentation fractionation. Three samples of bacteria were centrifuged from equal volumes $(280 \mathrm{ml}$.) of the 
same suspension ( $5 \mathrm{mg}$. dry wt. of bacteria/ml.) of freshly harvested and washed (with buffered saline) stationary-phase bacteria. Each sample was washed by centrifuging in one of three solutions $A, B$ and $C$ (Table 2) and, after disruption in the Hughes (1951) press, the product was resuspended in the same solution, homogenized and then fractionated. The analysis of the sedimentation fractions (Table 2: $R \mathrm{I}, R \mathrm{II}$ and $S I I$ ) showed that the composition of the fractions separated in a solution of $5 \mathrm{~mm}$-magnesium chloride in $0.145 \mathrm{M}$ sodium chloride was not significantly altered when the $\mathrm{pH}$ was increased from 6.5 (solution $A$ ) to $\mathbf{7 \cdot 4}$ (solution $B$ ). More material was recovered from the light-particulate fraction $(R$ II) with these solutions than with a solution $(C)$ of $0.1 \mathrm{~mm}$-magnesium

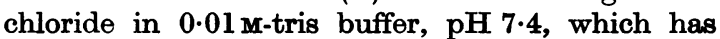
also been used for the isolation of ribosomes (Tissieres et al. 1959). With solution $C$, most of the protein, RNA and DNA, deficient in $R I I$, was present in the supernatant fraction SII. In view of these results, the solution with higher ionic strength and $\mathrm{Mg}^{2+}$ ion concentration at $\mathrm{pH} \mathrm{6.5}$ (solution $A$ ) was used.

Loss of protein and nucleic acids from sedimentation fractions of starved bacteria. Results are given in Table 3 for Expts. 1, 3, 5 and 6 of Table 1. Sus- pensions of disrupted bacteria ( $10 \%$ wet wt.) in a solution of 5 mM-magnesium chloride in $0.145 \mathrm{M}$ sodium chloride were either fractionated directly (Expt. 1) or after homogenizing (Expts. 3, 5 and 6). The effect of a preliminary homogenizing on the composition of sedimentation fractions from bacteria grown in tryptic meat broth is shown by comparing the results of Expt. 1 with those of Expt. 3, and the influence of the growth medium by comparing the results of Expt. 3 with the mean results of Expts. 5 and 6 (Table 3).

On considering the composition of bacteria grown in tryptic meat broth, the average loss of dry wt. $(1.13 \mathrm{mg} . / \mathrm{ml}$. or $23 \%)$ which occurred during starvation for $41 \mathrm{hr}$. (Table 1: Expts. 1-3) could be accounted for by losses of $0.97 \mathrm{mg}$. of protein $/ \mathrm{ml}$. (26\% of the total protein) and $0.13 \mathrm{mg}$. of RNA/ml. (25\% of the total RNA); the sum of losses from individual sedimentation fractions (0.92 mg. of protein $/ \mathrm{ml}$. and $0.14 \mathrm{mg}$. of RNA/ml.) showed good agreement with these results (Table 3 : Expts. 1 and 3). The preliminary homogenizing reduced the amounts of these constituents (Table 3: Expt. 3) in $R I$ and increased the amounts in both $R$ II and SII. Of the total losses of protein and RNA occurring during starvation in this experiment, 28 and $80-90 \%$ respectively were lost

Table 1. Changes in viability and dry weight of Aerobacter aerogenes during starvation

Bacteria from a fully-grown culture in tryptic meat broth (Expts. 1-3) or a carbon-limiting defined medium (Expts. 4-6) were starved (4.4-5 mg. dry wt. of bacteria/ml.) in buffered saline (pH 6.5) at $37^{\circ}$ with aeration. Experimental details are given in the text.

\begin{tabular}{|c|c|c|c|c|c|c|c|c|c|c|}
\hline \multirow{2}{*}{$\begin{array}{l}\text { Period of } \\
\text { starvation (hr.) }\end{array}$} & \multirow[b]{2}{*}{$\ldots$} & \multicolumn{3}{|c|}{$\begin{array}{c}\text { No. of viable bacteria } \\
\left(10^{10} / \mathrm{ml} .\right)\end{array}$} & \multicolumn{3}{|c|}{$\begin{array}{c}\text { Viability by mioroscopic } \\
\text { method }(\%)\end{array}$} & \multicolumn{3}{|c|}{$\begin{array}{l}\text { Bacterial dry wt. } \\
(\mathbf{m g} . / \mathrm{ml} .)\end{array}$} \\
\hline & & 0 & 17 & 41 & 0 & 17 & 41 & 0 & 17 & 41 \\
\hline $\begin{array}{r}\text { Expt. } 1 \\
\mathbf{2} \\
\mathbf{3} \\
\mathbf{4} \\
\mathbf{5} \\
\mathbf{6}\end{array}$ & & $\begin{array}{l}1.94 \\
1.97 \\
2 \cdot 4 \\
1.21 \\
1.31 \\
1.40\end{array}$ & $\begin{array}{l}2 \cdot 05 \\
1 \cdot 89 \\
2 \cdot 3 \\
1 \cdot 24 \\
1 \cdot 25 \\
1 \cdot 29\end{array}$ & $\begin{array}{l}2 \cdot 05 \\
1 \cdot 91 \\
2 \cdot 2 \\
1 \cdot 06 \\
1 \cdot 29 \\
1 \cdot 27\end{array}$ & $\begin{array}{l}98 \\
98 \\
94 \\
98 \\
90 \\
97\end{array}$ & $\begin{array}{l}96 \cdot 5 \\
98 \\
-\overline{98} \\
90 \\
97 \cdot 5\end{array}$ & $\begin{array}{l}- \\
\overline{-} \\
93 \\
91 \\
93 \cdot 6\end{array}$ & $\begin{array}{l}5 \cdot 0 \\
5 \cdot 0 \\
5 \cdot 0 \\
5 \cdot 0 \\
5 \cdot 0 \\
5 \cdot 0\end{array}$ & $\begin{array}{l}4 \cdot 02 \\
4 \cdot 05 \\
4 \cdot 05 \\
4 \cdot 55 \\
4 \cdot 26 \\
4 \cdot 15\end{array}$ & $\begin{array}{l}3 \cdot 92 \\
3 \cdot 98 \\
3 \cdot 71 \\
4 \cdot 34 \\
4 \cdot 04 \\
3 \cdot 95\end{array}$ \\
\hline
\end{tabular}

Table 2. Influence of the suspending fluid on the composition of sedimentation fractions obtained from Aerobacter aerogenes

A. aerogenes, from a fully grown culture in a carbon-limiting defined medium, were washed and suspended (5 mg. dry wt./ml.) in a solution of $5 \mathrm{~mm}-\mathrm{MgCl}_{2}$ in $0.145 \mathrm{M}-\mathrm{NaCl}$ at $\mathrm{pH} 6.5$ (solution $A$ ) or $\mathrm{pH} 7.4$ (solution $B$ ), or in a solution of $0.1 \mathrm{mM}-\mathrm{MgCl}_{2}$ in $0.01 \mathrm{M}$-tris buffer, $\mathrm{pH} 7.4$ (solution $C$ ). The bacteria were broken and fractionated into a heavy-particulate fraction $(R I)$, a light-particulate fraction ( $R I I)$ and a soluble fraction (SII). Experimental details are given in the text.

\begin{tabular}{|c|c|c|c|c|c|c|c|c|c|}
\hline \multirow[b]{2}{*}{ Suspending fluid $\ldots$} & \multicolumn{3}{|c|}{ Protein (mg./ml.) } & \multicolumn{3}{|c|}{ RNA (mg./ml.) } & \multicolumn{3}{|c|}{ DNA (mg./ml.) } \\
\hline & $A$ & $B$ & $\vec{C}$ & $A$ & $B$ & $\vec{C}$ & $A$ & $B$ & $\vec{C}$ \\
\hline $\begin{array}{c}\text { Unfractionated } \\
\text { disrupted bacteria } \\
R \text { I } \\
R \text { II } \\
S I I\end{array}$ & $\begin{array}{l}3 \cdot 48 \\
1 \cdot 12 \\
0 \cdot 94 \\
1 \cdot 18\end{array}$ & $\begin{array}{l}3 \cdot 68 \\
1.02 \\
0 \cdot 98 \\
1.38\end{array}$ & $\begin{array}{l}3 \cdot 54 \\
0 \cdot 70 \\
0 \cdot 80 \\
2 \cdot 04\end{array}$ & $\begin{array}{l}0.88 \\
0.11 \\
0.69 \\
0.081\end{array}$ & $\begin{array}{l}0.88 \\
0.10 \\
0.71 \\
0.086\end{array}$ & $\begin{array}{l}0.88 \\
0.06 \\
0.58 \\
0.30\end{array}$ & $\begin{array}{l}0.108 \\
0.01 \\
0.032 \\
0.079\end{array}$ & $\begin{array}{l}0.107 \\
0.006 \\
0.029 \\
0.080\end{array}$ & $\begin{array}{l}0.109 \\
0.005 \\
0.010 \\
0.120\end{array}$ \\
\hline
\end{tabular}


from $R \mathrm{II}$. The ratio of protein loss to RNA loss $(2 \cdot 1)$ was similar to the original ratio of these conconstituents (2). In $R I$ and $S I I$, on the other hand, the losses were mainly of protein.

With bacteria grown in $11 \mathrm{~N}$ medium, 0.67$1.05 \mathrm{mg}$. of dry wt. $/ \mathrm{ml}$. was lost during $41 \mathrm{hr}$. of starvation (Table 1: Expts. 4-6); variation was due mainly to a variation in protein losses. In Expts. 5 and 6 the losses in dry wt. were similar (about $1 \mathrm{mg} . / \mathrm{ml}$.); the means of the results for sedimentation fractions are therefore given in Table 3. During $41 \mathrm{hr}$. of starvation, $0.72 \mathrm{mg}$. of protein $/ \mathrm{ml}$. (21\% of the total protein) and $0.3 \mathrm{mg}$. of RNA/ml. (33\% of the total RNA) were lost; the sum of the losses from individual sedimentation fractions were $0.7 \mathrm{mg}$. of protein $/ \mathrm{ml}$. and $0.3 \mathrm{mg}$. of $\mathrm{RNA} / \mathrm{ml}$. Of the losses of total protein and of RNA, 29 and $72 \%$ respectively occurred from $R$ II. In this fraction the ratio of protein loss to RNA loss was 0.93 compared with the original ratio of these constituents of 1.32. As with bacteria grown in tryptic meat broth, the losses from $R I$ and $S I I$ were mainly of protein.

The ultracentrifuge patterns of disrupted bacterial suspensions prepared before and during starvation were similar and closely resembled those obtained by Bowen, Dagley \& Sykes, (1959; Fig. 1b) with Escherichia coli harvested at the end of the logarithmic phase.

During starvation the amount and distribution of DNA in bacteria grown in tryptic meat broth remained unchanged, whereas in bacteria grown in $11 \mathrm{~N}$ medium there was an increase in the amount of DNA ( $17 \%$ ) which was confined to $R \mathrm{I}$ (Table 3 : Expts. 5 and 6).
Products of degradation of protein and of ribonucleic acid. Previous results (Strange et al. 1961) indicated that the initial products of degradation were rapidly metabolized. Further information was obtained with a suspension of washed bacteria taken from a culture in $11 \mathrm{~N}$ medium. At intervals during starvation, samples were taken and centrifuged. The sedimented bacteria and the filtered suspending fluid were analysed for various constituents (Table 4).

The analysis of the products of RNA degradation showed that, during starvation, the ultraviolet-absorbing constituents increased only slightly in the cold-acid-soluble fraction of the cells but they increased substantially in the suspending fluid. The maximum absorption of the mixture of substances responsible was at $255 \mathrm{~m} \mu$, suggesting that extensive deamination of the primary products of nucleic acid degradation had occurred. Ionexchange fractionation showed the absence of any significant amounts of nucleotides. Paper ionophoresis showed the absence of guanosine, adenosine and cytidine, and the presence of small amounts of adenine and guanine. There was no inosine but a large amount of hypoxanthine. The techniques used did not distinguish between xanthine, uridine and uracil.

On assuming a mean molecular extinction coefficient, $\epsilon$, of 10800 at $255 \mathrm{~m} \mu$, derived from the deaminated bases from yeast RNA, the substances released in $44 \mathrm{hr}$. were equivalent to $0.27 \mathrm{mg}$. of RNA/ml., which nearly accounted for the loss of RNA (0.3 mg. of RNA $/ \mathrm{ml}$.). As shown by the Bial reaction (Morse \& Carter, 1949), the amounts of pentose-reacting substances were very low

Table 3. Changes in the composition of Aerobacter aerogenes during starvation

Bacteria were taken from a fully grown culture in either tryptic meat broth (Expts. 1 and 3) or a carbonlimiting defined medium (Expts. 5 and 6 ) and suspended (4.1-5 mg. dry wt. of bacteria/ml.) in buffered saline $\left(p \mathrm{H} \mathrm{6.5)}\right.$ at $37^{\circ}$ with aeration. At the times indicated, bacteria were isolated by centrifuging, disrupted and then fractionated, either with (Expts. 3, 5 and 6) or without (Expt. 1) preliminary homogenizing, into a heavyparticulate fraction $(R \mathrm{I})$, a light-particulate fraction $(R \mathrm{II})$ and a supernatant fraction $(S \mathrm{II})$. The results refer to a suspension initially containing $5 \mathrm{mg}$. dry wt. of bacteria/ml. The means of the results from Expts. 5 and 6 are given. Experimental details are given in the text.

\begin{tabular}{|c|c|c|c|c|c|c|c|c|c|c|c|c|c|}
\hline \multirow{2}{*}{\multicolumn{2}{|c|}{ Period of starvation (hr.) }} & \multicolumn{4}{|c|}{ Protein (mg./ml.) } & \multicolumn{4}{|c|}{ RNA (mg./ml.) } & \multicolumn{4}{|c|}{ DNA (mg./ml.) } \\
\hline & & 0 & 17 & 23 & 41 & 0 & 17 & 23 & 41 & 0 & 17 & 23 & 41 \\
\hline $\begin{array}{l}\text { Unfractionated } \\
\text { disrupted } \\
\text { bacteria }\end{array}$ & $\begin{array}{l}\text { Expt. } 1 \\
\text { Expt. } 3 \\
\text { Expts. 5, } 6\end{array}$ & $\begin{array}{l}3 \cdot 76 \\
3 \cdot 68 \\
3 \cdot 42\end{array}$ & $\begin{array}{l}2 \cdot 76 \\
2 \cdot 92 \\
2 \cdot 86\end{array}$ & $\begin{array}{l}2 \cdot 87 \\
2 \cdot 96 \\
2 \cdot 79\end{array}$ & $\begin{array}{l}2 \cdot 83 \\
2 \cdot 68 \\
2 \cdot 70\end{array}$ & $\begin{array}{l}0.56 \\
0.55 \\
0.91\end{array}$ & $\begin{array}{l}0 \cdot 44 \\
0.47 \\
0 \cdot 71\end{array}$ & $\begin{array}{l}0 \cdot 45 \\
0 \cdot 46 \\
0 \cdot 65\end{array}$ & $\begin{array}{l}0 \cdot 44 \\
0 \cdot 40 \\
0 \cdot 61\end{array}$ & $\begin{array}{l}-\overline{15} \\
0 \cdot 132\end{array}$ & $\begin{array}{l}-\overline{16} \\
0 \cdot 162\end{array}$ & $\begin{array}{l}\overline{-} \\
0 \cdot 16 \\
0 \cdot 155\end{array}$ & $\begin{array}{l}\overline{1} \\
0 \cdot 15 \\
0 \cdot 154\end{array}$ \\
\hline$R \mathrm{I}$ & $\begin{array}{l}\text { Expt. } 1 \\
\text { Expt. } 3 \\
\text { Expts. 5, } 6\end{array}$ & $\begin{array}{l}1 \cdot 65 \\
1 \cdot 44 \\
1 \cdot 24\end{array}$ & $\begin{array}{l}0.95 \\
1 \cdot 17 \\
0 \cdot 99\end{array}$ & $\begin{array}{l}1 \cdot 18 \\
1 \cdot 22 \\
0.96\end{array}$ & $\begin{array}{l}1 \cdot 11 \\
1 \cdot 22 \\
1 \cdot 01\end{array}$ & $\begin{array}{l}0 \cdot 21 \\
0 \cdot 09 \\
0 \cdot 16\end{array}$ & $\begin{array}{l}0.15 \\
0.07 \\
0.11\end{array}$ & $\begin{array}{l}0 \cdot 16 \\
0 \cdot 07 \\
0 \cdot 10\end{array}$ & $\begin{array}{l}0 \cdot 15 \\
0 \cdot 07 \\
0 \cdot 10\end{array}$ & $\begin{array}{l}-\overline{0} \\
0.039 \\
0.007\end{array}$ & $\begin{array}{l}-\overline{0} \\
0 \cdot 046 \\
0 \cdot 017\end{array}$ & $\begin{array}{l}-\overline{ } \\
0.033 \\
0.020\end{array}$ & $\begin{array}{l}-\overline{03} \\
0 \cdot 028\end{array}$ \\
\hline$R \mathrm{III}$ & $\begin{array}{l}\text { Expt. } 1 \\
\text { Expt. 3 } \\
\text { Expts. 5, } 6\end{array}$ & $\begin{array}{l}0.68 \\
0.76 \\
0.84\end{array}$ & $\begin{array}{l}0.57 \\
0.65 \\
0.65\end{array}$ & $\begin{array}{l}0.54 \\
0.59 \\
0.67\end{array}$ & $\begin{array}{l}0.57 \\
0.48 \\
0.64\end{array}$ & $\begin{array}{l}0 \cdot 35 \\
0 \cdot 38 \\
0 \cdot 65\end{array}$ & $\begin{array}{l}0 \cdot 30 \\
0 \cdot 33 \\
0 \cdot 48\end{array}$ & $\begin{array}{l}0 \cdot 30 \\
0 \cdot 29 \\
0 \cdot 45\end{array}$ & $\begin{array}{l}0 \cdot 28 \\
0 \cdot 27 \\
0 \cdot 44\end{array}$ & $\begin{array}{l}\overline{-} \\
0.063 \\
0.037\end{array}$ & $\begin{array}{l}\overline{-} \\
0.066 \\
0.034\end{array}$ & $\begin{array}{l}-\overline{0} \\
0.066 \\
0.036\end{array}$ & $\begin{array}{l}\overline{068} \\
0.036\end{array}$ \\
\hline$S \mathrm{II}$ & $\begin{array}{l}\text { Expt. 1 } \\
\text { Expt. 3 } \\
\text { Expts. 5, } 6\end{array}$ & $\begin{array}{l}1.48 \\
1.53 \\
1.27\end{array}$ & $\begin{array}{l}1 \cdot 14 \\
1 \cdot 16 \\
1 \cdot 04\end{array}$ & $\begin{array}{l}1.20 \\
1 \cdot 17 \\
1.03\end{array}$ & $\begin{array}{l}1.23 \\
1.06 \\
0.99\end{array}$ & $\begin{array}{l}0.062 \\
0.075 \\
0.087\end{array}$ & $\begin{array}{l}0 \cdot 057 \\
0 \cdot 063 \\
0 \cdot 085\end{array}$ & $\begin{array}{l}0.050 \\
0.063 \\
0.077\end{array}$ & $\begin{array}{l}0.053 \\
0.061 \\
0.071\end{array}$ & $\begin{array}{l}-\overline{-} \\
0.076 \\
0.087\end{array}$ & $\begin{array}{l}-\overline{0} \\
0.070 \\
0.079\end{array}$ & $\overline{\bar{Z}}$ & $\begin{array}{l}-\overline{08 c} \\
0 \cdot 09\end{array}$ \\
\hline
\end{tabular}




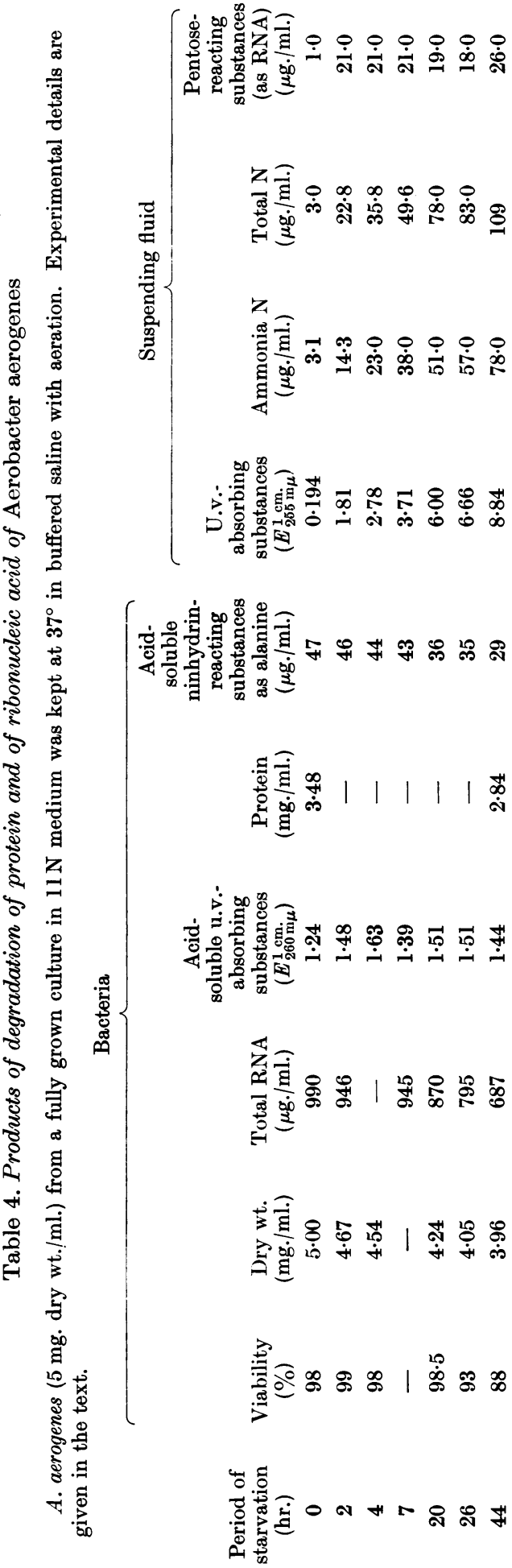

(Table 4), confirming the absence of large amounts of nucleosides.

The analysis of the products of protein degradation showed that, during starvation, the cold-acidsoluble endogenous ninhydrin-reacting constituents decreased (Table 4), whereas the ammonia in the suspending fluid increased. The examination of the desalted suspending fluid by paper chromatography, before and after acid hydrolysis (with $6 \mathrm{~N}$-hydrochloric acid at $106^{\circ}$ for $20 \mathrm{hr}$.), indicated that only traces of free amino acids, peptides (and protein) were present. Certain ninhydrin-reacting substances not identified as free amino acids or as putrescine or cadaverine were also present on the chromatograms of unhydrolysed samples. The concentration of these increased during starvation and, in a phenol solvent in an atmosphere of ammonia, they moved just short of the solvent front. The differences between values for ammonia $\mathrm{N}$ and total $\mathbf{N}$ in the suspending fluid may be accounted for by products of RNA degradation.

\section{DISCUSSION}

The different mean cell sizes and RNA contents of the bacteria obtained from the complex and defined media are probably due to variations in the growth rates (Caspersson, 1947; Malmgren \& Heden, 1947; Caldwell, Mackor \& Hinshelwood, 1950; Herbert, 1961) and the speed with which the culture passes into the stationary phase. In the complex medium the passage is gradual and accompanied by a reduction in the concentration of RNA : in $11 \mathrm{~N}$ medium it is rapid and the high concentration of RNA existing during rapid growth remains in the stationary phase (Fig. 2 of Herbert, 1961).

During starvation, the degradation of the major constituents of the bacteria appears to be related to the initial concentrations of these substances. In glycogen-rich $A$. aerogenes, for example, the polysaccharide is rapidly degraded and losses of RNA and protein are relatively small (Strange et al. 1961). In the present experiments, in which the bacteria have little polysaccharide reserve, the RNA-rich bacteria from the defined medium degrade more of their RNA and less of their protein than bacteria from the complex medium.

As expected, the separation of sedimentation fractions was influenced by the ionic strength of the suspending fluid, but in some respects the results obtained (Table 2) were not as would have been expected from previous reports. In agreement with previous observations (Schachman, Pardee \& Stanier, 1952; Dagley \& Sykes, 1956; Wade \& Morgan, 1957) the ultracentrifuge diagram obtained with solutions of $I 0 \cdot 15$ showed the presence of components in the range 20-40s. Although 
with low-ionic-strength solution $\left(\begin{array}{ll}I & 0.01\end{array}\right)$ Tissieres et al. (1959) obtained generally faster-moving components (30s and $50 \mathrm{~s}$ ) with purified ribosome preparations, with similar conditions we obtained a lower recovery of ribosomes (Table 2). The $30 \mathrm{~s}$ and $50 \mathrm{~s}$ ribosomes obtained by cycles of precipitation with $\mathrm{Mg}^{2+}$ ions (Tissieres et al. 1959) may not be representative of the natural complement in the bacteria.

The medium used for growth influenced both the amount and the composition of the ribosomal fraction obtained with the solution of higher ionic strength (Fig. 1: $R$ II). In bacteria from the defined medium the losses of protein and RNA from $R$ II were equivalent (Table 3: Expts. 5 and 6 ), suggesting that the loss is due to ribosomal protein and not to a contaminating protein. The higher protein: RNA ratio in the ribosomal fraction from bacteria grown in tryptic meat broth may be due to a greater contamination from non-ribosomal protein.

In this, as in the experiments of Strange et al. (1961), there was no significant change in the number of bacteria during starvation; the increase observed in the DNA of bacteria from the defined medium was probably not accompanied by cell division. The confinement of the increase to $R \mathrm{I}$ (Table 3: Expts. 5 and 6) is in agreement with the results of Goldstein \& Brown (1961), who found DNA with high specific activity in a similar fraction from $E$. coli when they exposed exponentially growing bacteria to ${ }^{32} \mathrm{P}$ [phosphate].

During starvation of $E$. coli for $4 \mathrm{hr}$. at $35^{\circ}$, a turnover without net loss of protein occurred (Mandelstam, 1957, 1958), and this situation existed with ribosomal protein although there was a net loss of ribosomal RNA (Mandelstam \& Halvorson, 1960). The present results show that, during a $41 \mathrm{hr}$. period of starvation at $37^{\circ}$, there are considerable losses of protein from all the sedimentation fractions in $A$. aerogenes. At least in bacteria from the defined medium, these losses are not accompanied by an accumulation of amino acids but $73 \%$ of the protein $\mathrm{N}$ appears in the suspending fluid as ammonia.

The products of RNA breakdown are also rapidly released into the suspending fluid and eventually appear mainly as free bases, including hypoxanthine.

From their studies on E. coli, Mandelstam \& Halvorson (1960) concluded that, in addition to their function in bacteria as essential sites of protein synthesis, ribonucleoprotein particles act as a reservoir which supplies almost one-half of the amino acids and virtually all the ribonucleotides passing through the free pools during starvation, and that this involves the loss of RNA but not of protein. The results here with $A$. aerogenes suggest that more extensive starvation involves the degradation of protein, including that in ribosomes, and ribosomal RNA.

\section{SUMMARY}

1. The changes in protein and nucleic acid composition of fractions sedimented from starved viable Aerobacter aerogenes held at $37^{\circ}$ with aeration have been investigated with bacteria grown in tryptic meat broth and a carbon-limiting defined medium (11N).

2. Disrupted bacteria were homogenized in a solution of $5 \mathrm{~mm}$-magnesium chloride in $0.145 \mathrm{M}$ sodium chloride and fractionated into a heavyparticulate fraction $(R \mathrm{I})$, a light-particulate fraction ( $R I I)$ which contained the ribosomes, and a supernatant fraction (SII). Changes during starvation in the amounts of protein and of nucleic acids in these fractions are described.

3. In bacteria grown in $11 \mathrm{~N}$ medium, the degradation of protein during storage resulted in the release of ammonia and traces of amino acids into the suspending medium, and was accompanied by a decrease in the concentration of endogenous amino acids. The degradation of ribosomal RNA did not increase the amount of RNA in the supernatant fraction. The degradation products of RNA, mainly deaminated bases, were rapidly released into the suspending medium.

We are grateful to Dr K. Cammack for the ultracentrifugal diagrams.

\section{REFERENCES}

Bolognani, L., Coppi, G. \& Zambotti, V. (1961). Experientia, 17, 67.

Borek, E., Ryan, A. \& Rockenbach, J. (1955). J. Bact. 69, 460.

Bowen, T. J., Dagley, S. \& Sykes, J. (1959). Biochem. J. 72, 419.

Burton, K. (1956). Biochem. J. 62, 315.

Caldwell, P. C., Mackor, E. L. \& Hinshelwood, C. (1950). J. chem. Soc., p. 3151.

Caspersson, T. (1947). Symp. Soc. exp. Biol. 1, 127.

Dagley, S. \& Sykes, J. (1956). Arch. Biochem. Biophys. 62, 338.

Disohe, Z. \& Borenfreund, E. (1957). Biochim. biophys. Acta, 23, 639.

Goldstein, A. \& Brown, B. J. (1961). Biochim. biophys. Acta, 53, 19.

Herbert, D. (1961). Symp. Soc. gen. Microbiol. 11, 391.

Higuchi, M. \& Uemura, T. (1959). Nature, Lond., 184, 1381.

Holden, J. T. (1958). Biochim. biophys. Acta, 29, 667.

Hughes, D. E. (1951). Brit. J. exp. Path. 32, 97.

Lovett, S. \& Wright, W. C. (1961). Chem. \& Ind., p. 1433.

Mackie, T. J. \& McCartney, J. E. (1948). In Handbook of Practical Bacteriology, 8th ed., p. 146. Edinburgh: E. and S. Livingstone Ltd.

Malmgren, B. \& Heden, C. (1947). Acta path. microbiol. scand. 24, 448. 
Mandelstam, J. (1957). Nature, Lond., 179, 1179.

Mandelstam, J. (1958). Biochem. J. 69, 110.

Mandelstam, J. \& Halvorson, H. (1960). Biochim. biophys. Acta, 40, 43.

Morse, M. L. \& Carter, C. E. (1949). J. Bact. 58, 317.

Postgate, J. R., Crumpton, J. E. \& Hunter, J. R. (1961). J. gen. Microbiol. 24, 15.

Rotman, B. (1958). J. Bact. 76, 1.

Schachman, H. K., Pardee, A. B. \& Stanier, R. Y. (1952). Arch. Biochem. Biophys. 38, 245.

Schneider, W. C. (1945). J. biol. Chem. 161, 293.

Stickland, L. H. (1951). J. gen. Microbiol. 5, 698.
Strange, R. E. (1961). Nature, Lond., 191, 1272.

Strange, R. E., Dark, F. A. \& Ness, A. G. (1961). J. gen. Microbiol. 25, 61.

Tissieres, A., Watson, J. D., Schlessinger, D. \& Hollingworth, B. R. (1959). J. molec. Biol. 1, 221.

Tracey, M. V. (1952). Biochem. J. 52, 265.

Wade, H. E. (1960). Biochem. J. 77, 534.

Wade, H. E. (1961). Biochem. J. 78, 457.

Wade, H. E. \& Lovett, S. (1961). Biochem. J. 81, 319.

Wade, H. E. \& Morgan, D. M. (1957). Biochem. J. 65, 321.

Yemm, E. W. \& Cocking, E. C. (1955). Analyst, 80, 209.

Biochem. J. (1963) 86, 203

\title{
Excretion of Various Porphyrins and their Corresponding Porphyrinogens by Rabbits after Intravenous Injection
}

\author{
By SEIYO SANO* AND C. RIMINGTON \\ Department of Chemical Pathology, University College Hospital Medical School, London, W.C. 1
}

(Received 8 August 1962)

Numerous investigations have been conducted on the fate of various porphyrins after ingestion or injection without an intermediary metabolism of porphyrins having been conclusively established. Recent biochemical evidence shows that the actual intermediates in the biosynthesis of haem are not porphyrins, however, but their reduction products, the porphyrinogens, derivable from hexahydroporphin. The chemistry of these readily autoxidizable substances has been studied, but their behaviour and metabolism in vivo is still unknown. That they occur in vivo is certain but several questions remain unanswered, e.g.: (1) By what mechanism are the tetrapyrrole pigments kept in vivo in the reduced form as porphyrinogens? (2) Do porphyrinogens combine with proteins? (3) Is any protoporphyrinogen found in vivo? (4) Do porphyrins normally occur in vivo? (5) If so, at what stage and in what site does the oxidation of porphyrinogen to porphyrin occur? (6) What factors control the urinary excretion of porphyrins and porphyrinogens; is there a relation to the number of carboxylic functions in the molecule?

That a considerable fraction of the urinary coproporphyrin ('urospectrine') existed in fresh specimens as a colourless precursor was reported by Saillet (1896); but this observation was neglected until Watson, de Mello, Schwartz, Hawkinson \& Bossenmaier (1951) showed that the non-fluorescent chromogen was in many respects similar to chemically prepared coproporphyrinogen and was

\footnotetext{
* Present address: Department of Public Health,
} Faculty of Medicine, Kyoto University, Kyoto, Japan. readily oxidized to coproporphyrin by dilute iodine. In fresh urines, 25-66\% of the coproporphyrin was present as precursor. Holeček $(1957 a)$ found that with appropriate precautions $97 \%$ of the total could be identified as porphyrinogen. Weatherall (1952) found in rabbits that injected coproporphyrin III was eliminated in the bile and not the urine, and suggested that in lead-poisoned animals it was entirely coproporphyrinogen that gave rise to the high urinary coproporphyrin concentrations found by the usual methods of determination. Hoffbauer, Watson \& Schwartz (1953) showed that coproporphyrin injected into the normal rat did not appear in the urine whereas with animals poisoned by carbon tetrachloride a proportion of the dose was so eliminated. Using rabbits, Heikel, Knight, Rimington, Ritchie \& Williams (1960) compared the behaviour of intravenously injected coproporphyrinogen III and coproporphyrin III. Both were eliminated in part in the fistula bile, but, whereas coproporphyrinogen passed readily into the urine, no such elimination of injected coproporphyrin occurred.

The present paper describes further studies on the excretion of various porphyrins and porphyrinogens after their intravenous injection into rabbits.

\section{EXPERIMENTAL}

\section{Animals}

Male adult rabbits weighing 2-2.5 kg. were used. An indwelling urinary catheter was inserted and urine was collected for analysis every $2 \mathrm{hr}$. after the intravenous 